\title{
The KOF Globalisation Index - revisited
}

\section{Savina Gygli ${ }^{1}$ - Florian Haelg ${ }^{2}$ • Niklas Potrafke ${ }^{3,4} \cdot$ Jan-Egbert Sturm $^{2,5}$ (D)}

Published online: 28 January 2019

(C) The Author(s) 2019

\begin{abstract}
We introduce the revised version of the KOF Globalisation Index, a composite index measuring globalization for every country in the world along the economic, social and political dimension. The original index was introduced by Dreher (Applied Economics, 38(10):1091-1110, 2006) and updated in Dreher et al. (2008). This second revision of the index distinguishes between de facto and de jure measures along the different dimensions of globalization. We also disentangle trade and financial globalization within the economic dimension of globalization and use time-varying weighting of the variables. The new index is based on 43 instead of 23 variables in the previous version. Following Dreher (Applied Economics, 38(10):1091-1110, 2006), we use the new index to examine the effect of globalization on economic growth. The results suggest that de facto and de jure globalization influence economic growth differently. Future research should use the new KOF Globalisation Index to re-examine other important consequences of globalization and why globalization was proceeding rapidly in some countries, such as South Korea, but less so in others. The KOF Globalisation Index can be downloaded from http:/www.kof.ethz.ch/globalisation/.
\end{abstract}

Keywords Globalization · Composite indicators

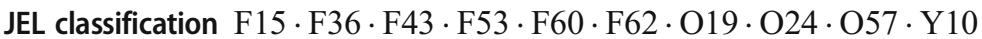

Electronic supplementary material The online version of this article (https://doi.org/10.1007/s11558-01909344-2) contains supplementary material, which is available to authorized users.

Florian Haelg

haelg@kof.ethz.ch

$1 \quad$ SNB, Zurich, Switzerland

2 KOF Swiss Economic Institute, ETH Zurich, Leonhardstrasse 21, 8092 Zurich, Switzerland

3 Ifo Institute, Munich, Germany

4 University of Munich, Munich, Germany

5 CESifo Munich, Munich, Germany 


\section{Introduction}

How globalization influences our daily lives is still a controversial issue. In fact, globalization was proceeding rapidly for a long time and it was hard to believe that globalization would be pushed back. In 2018, however, US president Donald Trump reintroduced tariffs and initiated tariff wars. Trump did what he promised during his election campaign and what many citizens and scholars did not believe a Republican president would do: protectionist policies. Trump also intimidated his Western allies at the G7 and NATO summits - giving rise to the question of whether new political alliances are likely to be established. Citizens in the United Kingdom voted to leave the European Union (Brexit). The United Kingdom and the European Union negotiate the withdrawal agreement. It is conceivable that a new era of globalization has begun in 2018 .

To examine consequences and causes of globalization in more detail, we need to measure globalization. Single indicators, often reflecting openness, such as trade as a percentage of GDP, are frequently used as a proxy for globalization. Globalization is, however, a multifaceted concept that encompasses much more than openness to trade and capital flows. It also includes citizens of different countries communicating with each other and exchanging ideas and information, or governments working together to tackle political problems of global reach. Consequently, scholars need to account for manifold facets of globalization. Composite indicators, such as the KOF Globalisation Index, are cases in point because they allow combining different variables, measuring different aspects of globalization, into one index. Several composite indicators measuring globalization have been proposed. The KOF Globalisation Index, introduced by Dreher (2006) and updated in Dreher et al. (2008), measures globalization along the economic, social and political dimension for almost every country in the world since 1970. It has become the most widely used globalization index in the academic literature (Potrafke 2015).

We introduce the second revision of the KOF Globalisation Index. We propose an index that allows for flexible aggregation of different dimensions and characteristics of globalization. The revised version of the KOF Globalisation Index distinguishes between de facto and de jure globalization. While de facto globalization measures actual international flows and activities, de jure globalization measures policies and conditions that, in principle, enable, facilitate and foster flows and activities. Quinn et al. (2011) show, for example, that the decision to use either de facto or de jure measures of financial openness gives rise to systematically different findings in the financial openness-economic growth nexus. We propose a separate de facto and de jure globalization index and maintain this distinction within every dimension and subdimension of the index. The overall KOF Globalisation Index combines de facto and de jure globalization (Table 1 shows the individual components). We thus follow related studies such as Feld and Voigt (2003) and Voigt et al. (2015) that have shown how important it is to distinguish between de facto and de jure elements of institutions, policies and their potential outcomes.

The revision of the KOF Globalisation Index also includes other new components: we disentangle trade and financial globalization within the economic dimension of globalization, we allow the weights of the underlying variables to vary over time and we define cultural globalization in a broader way. Some variables from the 2007 version of the KOF Globalisation Index are replaced, and many new variables, 
Table 1 Structure of the KOF Globalisation Index

\begin{tabular}{|c|c|c|c|}
\hline Globalisation Index, de facto & Weights & Globalisation Index, de jure & Weights \\
\hline Economic Globalisation, de facto & 33.3 & Economic Globalisation, de jure & 33.3 \\
\hline Trade Globalisation, de facto & 50.0 & Trade Globalisation, de jure & 50.0 \\
\hline Trade in goods & 38.8 & Trade regulations & 26.8 \\
\hline Trade in services & 44.7 & Trade taxes & 24.4 \\
\hline \multirow[t]{2}{*}{ Trade partner diversity } & 16.5 & Tariffs & 25.6 \\
\hline & & Trade agreements & 23.2 \\
\hline Financial Globalisation, de facto & 50.0 & Financial Globalisation, de jure & 50.0 \\
\hline Foreign direct investment & 26.7 & Investment restrictions & 33.3 \\
\hline Portfolio investment & 16.5 & Capital account openness & 38.5 \\
\hline International debt & 27.6 & International Investment Agreements & 28.2 \\
\hline International reserves & 2.1 & & \\
\hline International income payments & 27.1 & & \\
\hline Social Globalisation, de facto & 33.3 & Social Globalisation, de jure & 33.3 \\
\hline Interpersonal Globalisation, de facto & 33.3 & Interpersonal Globalisation, de jure & 33.3 \\
\hline International voice traffic & 20.8 & Telephone subscriptions & 39.9 \\
\hline Transfers & 21.9 & Freedom to visit & 32.7 \\
\hline International tourism & 21.0 & International airports & 27.4 \\
\hline International students & 19.1 & & \\
\hline Migration & 17.2 & & \\
\hline Informational Globalisation, de facto & 33.3 & Informational Globalisation, de jure & 33.3 \\
\hline Used internet bandwidth & 37.2 & Television access & 36.8 \\
\hline International patents & 28.3 & Internet access & 42.6 \\
\hline High technology exports & 34.5 & Press freedom & 20.6 \\
\hline Cultural Globalisation, de facto & 33.3 & Cultural Globalisation, de jure & 33.3 \\
\hline Trade in cultural goods & 28.1 & Gender parity & 24.7 \\
\hline Trade in personal services & 24.6 & Human capital & 41.4 \\
\hline International trademarks & 9.7 & Civil liberties & 33.9 \\
\hline McDonald's restaurant & 21.6 & & \\
\hline IKEA stores & 16.0 & & \\
\hline Political Globalisation, de facto & 33.3 & Political Globalisation, de jure & 33.3 \\
\hline Embassies & 36.5 & International organisations & 36.2 \\
\hline UN peace keeping missions & 25.7 & International treaties & 33.4 \\
\hline International NGOs & 37.8 & Treaty partner diversity & 30.4 \\
\hline
\end{tabular}

Weights in percent for the year 2016. Weights for the individual variables are time variant. Overall indices for each aggregation level are calculated by the average of the respective de facto and de jure indices

especially measuring de jure characteristics of globalization, are introduced. The total number of underlying variables had increased from 23 to 43 compared to the previous version of the index.

Following Dreher (2006), we use the new index to examine the effect of globalization on economic growth. The results suggest that de facto and de jure globalization 
influence economic growth in different manners. Future research should use the new KOF Globalisation Index to re-examine other important consequences of globalization and why globalization was proceeding rapidly in some countries, such as South Korea, but less so in others.

The rest of the paper is structured as follows. Section 2 deals with measuring globalization and summarizes related literature while focusing on as of how to improve the KOF Globalisation Index. Section 3 describes how the new version of the KOF Globalisation Index is constructed. Section 4 describes differences between the previous and new version. Section 5 includes our application to economic growth. Section 6 concludes.

\section{Measuring globalization}

\subsection{Defining globalization}

Designing a composite indicator measuring globalization requires a definition of globalization. Our definition of globalization stems from Dreher (2006) and is based on Clark (2000) and Norris (2000):

Globalization describes the process of creating networks of connections among actors at intra- or multi-continental distances, mediated through a variety of flows including people, information and ideas, capital, and goods. Globalization is a process that erodes national boundaries, integrates national economies, cultures, technologies and governance, and produces complex relations of mutual interdependence.

We follow Dreher (2006), who, based on Nye and Keohane (2000), distinguishes between three different dimensions of globalization. Economic globalization characterizes long distance flows of goods, capital and services as well as information and perceptions that accompany market exchanges. Social globalization expresses the spread of ideas, information, images and people. Political globalization characterizes the diffusion of government policies.

Scholte (2008) and Caselli (2012) propose that globalization differs from similar concepts such as internationalization, liberalization, universalization or Westernization. According to them globalization is the spread of trans-planetary or supra-territorial connections between people. Internationalization refers to an increase in transactions and interdependencies between countries. Liberalization denotes the process of removing officially imposed restrictions on movements of resources between countries. Universalization describes the process of dispersing various objects and experiences to people at all inhabited parts of earth. Westernization is interpreted as a particular type of universalization, in which social structures of Western societies are spread across earth. All of these concepts are close to each other and sometimes used interchangeably. A clear distinction would be helpful, but is difficult to achieve. We therefore agree with Figge and Martens (2014), who claim that a distinction of all these concepts is not needed, when a pluralistic and multiscale definition of globalization is employed. 


\subsection{Literature and critique}

\subsubsection{Previous measures of globalization}

Scholars were active in constructing encompassing indicators of globalization since the early 2000s (for an overview of some of the most popular globalization indices, see Table 2). The A.T. Kearney/Foreign Policy Globalisation Index (ATK/FP) was one of the first globalization indices, launched in 2001 and continued until 2006, and has served as a prototype for many later indices (A.T. Kearney/Foreign Policy 2001). Developed almost simultaneously, the KOF Globalisation Index followed in 2002 and was updated in 2007 (Dreher 2006 and Dreher et al. 2008). The Centre for the Study of Globalisation and Regionalisation (CSGR) at the University of Warwick produced the CSGR Globalisation Index for the years 1982-2004, measuring the economic, social and political dimension of globalization using 16 variables and determining the weights by the means of principal components (Lockwood and Redoano 2005). A distinguishing feature of the CSGR Globalisation Index is that variables measuring openness are adjusted for country characteristics such as initial population size, land area and whether a country is landlocked or not. It therefore measures a country's level of globalization conditional on its potential.

Kluver and Fu (2004) calculated the Cultural Globalization Index, which measured the global spread of ideas by trade in media related goods between countries. Raab et al. (2008) attempted to include the sociological concept of globalization and extended the cultural dimension of globalization with variables related to the international convergence of norms and values in their so-called GlobalIndex. The Maastricht Globalisation Index (MGI) included the environmental dimension, represented by the ecological footprint of exports and imports as a share of bio capacity (Figge and Martens 2014). The New Globalisation Index (NGI) introduced distance weighting of some of the variables to better distinguish globalization from regionalization (Vujakovic 2010). The DHL Connectedness Index, measuring connectedness rather than globalization, distinguished between depth and breadth of integration along the different dimensions of globalization (Ghemawat and Altman 2016).

The KOF Globalisation Index is arguably the most popular globalization index. It encompasses a large panel dataset including 203 countries and territories and spans from 1970 to 2016. The data is easily accessible and a yearly update increases its timespan annually. ${ }^{1}$ Potrafke (2015) reviews 120 empirical studies that use the 2007 version of the KOF Globalisation Index.

Scholars are also active in discussing a suitable definition of globalization and characteristics that have to be accounted for when measuring globalization. ${ }^{2} \mathrm{We}$ describe different issues concerning the measurement of globalization defined by Martens et al. (2015) to arrive at how we design the revised KOF Globalisation Index: (i) the focus of measurement, (ii) the unit of measurement, (iii) the dimensions of globalization, (v) the differentiation between globalization and regionalization and, (vi) the transformation of variables in the light of country-specific factors.

\footnotetext{
${ }^{1}$ The KOF Globalisation Index is available at http://www.kof.ethz.ch/globalisation.

${ }^{2}$ See, among others, Dreher et al. (2008), Dreher et al. (2010), OECD (2010), Caselli (2012) and Martens et al. (2015).
} 


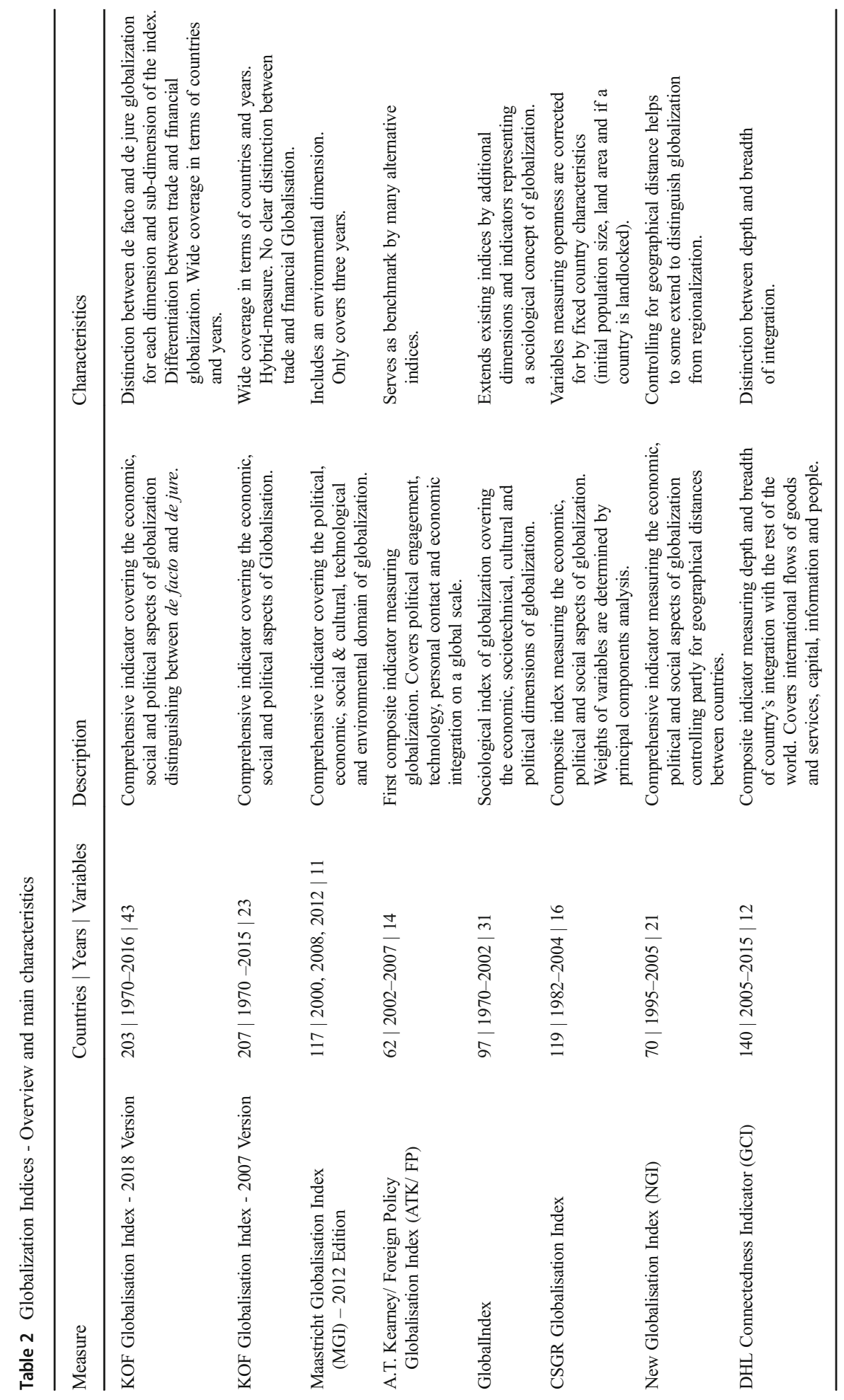




\subsubsection{Focus of measurement: De facto globalization and globalization policies}

Globalization indices differ by their focus of measurement such as de facto globalization or globalization policies and conditions, also called de jure measures. While de facto globalization measures actual flows and activities, de jure globalization measures policies, resources, conditions and institutions that, in principle, enable or facilitate actual flows and activities. Most globalization indices focus on de facto globalization. Exceptions are the 2007 version of the KOF Globalisation Index and the GlobalIndex by Raab et al. (2008). Both combine de facto and de jure measures, labelled as actual flows and restrictions, within the economic dimension of globalization. ${ }^{3}$

Martens et al. (2015) advocate a sharp distinction between de facto and de jure measures of globalization. De facto and de jure measures may well differ substantially, when, for example, a policy is strict on paper, but toothless in practice (Kose et al. 2009). When investigating the relationship between financial openness and economic growth, Quinn et al. (2011) show that the choice of financial openness indicators influences the results a great deal. De jure financial openness was positively correlated with economic growth, de facto financial openness lacked statistical significance. In the revised KOF Globalisation Index, we propose to disentangle de facto and de jure measures of globalization in all dimensions and sub-dimensions of the index.

\subsubsection{Unit of measurement: National, subnational or individual}

The KOF Globalisation Index focuses, as most other globalization indices, on measuring globalization at the national level. This has drawbacks: it omits all within country transactions and often neglects the geographical distribution of linkages (Martens et al. 2015). Moreover, concentrating on the national perspective conflicts with the notion that globalization erodes national borders, reducing the importance of nation states. Given the distinct feature of globalization being its supra-territoriality, as opposed to internationalization, Scholte (2008) raises the question on how to justify using the nation state as the main unit of measurement. Consequently, indices that depart from the perspective of nation states have been proposed, such as the Person-Based Globalisation Index (PBGI) by Caselli (2013) and the Global Cities Index (GCI) by A.T. Kearney (2018). They provide new perspectives and additional insights to the multidimensional concept of globalization. There are, however, some good reasons to focus on the national perspective when measuring globalization. National governments remain the main actors in shaping the globalization process and nations continue to be the reference points for most people today (Martens et al. 2015). Finally, data availability is highest at the national level.

\subsubsection{Dimensions of globalization: Economic, social and political dimension}

The KOF Globalisation Index distinguishes between the economic, social and political dimensions of globalization. Economic globalization includes trade and financial

\footnotetext{
${ }^{3}$ In the 2007 version of the KOF Globalisation Index, the sub-dimension actual flows includes variables on trade and capital flows, clearly a de facto measure of globalisation. The sub-dimension restrictions, includes variables on import barriers and tariff rates and can be categorised as de jure measure of globalisation.
} 
globalization. Social globalization includes interpersonal, informational and cultural globalization. Figge and Martens (2014) propose two additional dimensions in the Maastricht Globalisation Index: technological and ecological globalization. While technological globalization includes measures of communication technology that overlap with the social dimension of the KOF Globalisation Index, the ecological dimension is a distinct feature of the Maastricht Globalisation Index.

Cultural globalization as part of social globalization is the most difficult dimension to grasp. The initial definition of cultural globalization in the KOF Globalisation Index goes back to Saich (2000) and Rosendorf (2000) who defined it as the international dispersion of Western and in particular American values. This view has been criticized as being too much focused on Western cultural peculiarities and its global spread (Raab et al. 2008; Dreher et al. 2010 and Martens et al. 2015). Raab et al. (2008) take a more refined look at cultural globalization, trying to abstain from focusing too much on Western culture. Following sociological studies on international cultural diffusion, the authors include variables measuring the spread of values and standards of rationalism around the world. They interpret the diffusion of such values as globalization in cultural affairs. Kluver and $\mathrm{Fu}(2004)$ note that transmission of cultural values is closely related to sharing cultural goods and services such as movies, TV series, music and other works of art across borders. Disdier et al. (2010) use bilateral trade in cultural goods as a proxy for countries' cultural proximity. Hellmanzik and Schmitz (2015) use trade in audio-visual services based on bilateral hyperlinks and bilateral website visits as a proxy for cultural proximity. In the revised KOF Globalisation Index, we propose a broader definition of cultural globalization inspired by Raab et al. (2008) and include additional variables compared to the previous version of the index.

\subsubsection{Globalization versus regionalism: Accounting for distances, intensities and networks}

Most globalization indices do not consider distances, intensities and network sizes in the calculation of their index. In that sense, globalization can often not be distinguished from related concepts such as openness or regionalism (Vujakovic 2010; Martens et al. 2015). A classic example is trade, usually employed as the sum of total exports and imports in percent of GDP. A country may increase its trade to GDP ratio by trading a great deal with neighboring countries (Mexico for example exports over $80 \%$ of its goods to the United States) or by trading with many countries at larger global distances. While trading with neighboring countries rather describes regionalism, trading with many countries at larger distances can be regarded as globalization. To account for these shortcomings, Vujakovic (2010) proposes to weight trade data with the bilateral distance between the capital cities. Greater distances give rise to higher weighted trade, which indicates a higher degree of globalization.

The DHL Connectedness Index is a more recent attempt to account for networks in the definition of globalization (Ghemawat and Altman 2016). The DHL Connectedness Index defines globalization as the concentration of relationships across borders. Countries maintaining smaller numbers of international connections are assigned lower levels of globalization than countries that maintain connections with many partners, independent of locations or distances. Babones and Farabee-Siers (2008), De Lombaerde and Iapadre (2008) and OECD (2010) propose to include variables that 
indicate a country's trading partner concentration, calculated using the HerfindahlHirschmann concentration index, as a proxy for the trading partner network.

The drawback of all methods that account for the geographical distribution of linkages is that bilateral data is needed for the calculation. However, bilateral information is only available for few variables, such as trade in goods or bilateral treaties. In the revised KOF Globalisation Index, we account for network effects to some extent, by including variables measuring trading partner diversity and treaty partner diversity in the economic and political dimension, respectively. Both diversity variables are calculated as the inverse of the Herfindahl-Hirschmann concentration index.

\subsubsection{Transformation of variables: Shall we account for country-specific factors?}

The outcome of many variables, in particular most de facto variables, is influenced by exogenous and country-specific factors. Larger countries exhibit, for example, higher trade volumes in absolute terms. Landlocked countries are less integrated in world markets than countries with access to the sea because of higher transport costs. Hence, constructing a globalization index includes deciding on how to deal with the influence of such exogenous factors. The 2007 version of the KOF Globalisation Index accounts for the size of a country by dividing variables by GDP or population size. This procedure is maintained in the revised version of the index. Lockwood (2004) proposes a more rigorous way of controlling for geographical characteristics of a country: he regresses each variable on exogenous factors such as population, land area and whether a country is landlocked. The residuals of such regressions, which describe the difference between the predicted value based on geographical characteristics and the actual value of the variable, are included in the index. Lockwood and Redoano (2005) use this technique to transform all economic variables related to openness in the CSGR Globalisation Index. Vujakovic (2010) also transforms different variables included in her globalization index. She shows that the transformation favors bigger countries, assigning them higher levels of globalization than they otherwise would have had. However, it goes beyond the treatment of variables that is suggested by the definition of globalization in Clark (2000), Norris (2000) and Nye and Keohane (2000). These authors describe globalization as a process that connects actors, which does not call for more than a correction of size effects.

\section{The KOF Globalisation Index revisited}

\subsection{Content of revision}

Whereas this revision does lead to some substantial changes as compared to the previous version of the KOF Globalisation Index, we are still constrained by a number of factors in the selection of the variables. While we wish to consider as many individual variables as possible to portray the multifaceted concept of globalization and to exploit their variation when using principal component analysis, we rely on variables with a broad coverage that are updated regularly. We need variables that cover basically all countries in the world from 1970 onwards. This excludes many variables that are, for example, collected for OECD countries only. Because we continue to 
release an update of the KOF Globalisation Index on a yearly basis, we need variables of which we know that these will be regularly updated and published. Furthermore, using principal components analysis to determine the weights of the individual variables requires a minimum number of variables. As we do not want a single variable to dominate one particular sub-dimension, we employ the rule that for each subdimension we need at least three variables. Distinguishing between de facto and de jure globalization in every sub-dimension (trade, financial, interpersonal, informational, cultural and political) requires a minimum set of 36 variables.

\subsubsection{Distinction between de facto and de jure globalization}

The new KOF Globalisation Index distinguishes between de facto and de jure measures of globalization. We compute a separate index for the de facto and de jure economic, social and political dimensions of globalization. On the sub-dimensional level, we compute a separate index for de facto and de jure trade, financial, interpersonal, informational and cultural globalization. Some variables in the 2007 version of the KOF Globalisation Index measure the possibility for information exchange between international actors. These variables include access to television and internet and are reclassified as de jure indicators in the revised KOF Globalisation Index. Many new variables, especially measuring de jure globalization, are introduced.

\subsubsection{Distinction between trade and financial globalization}

The economic dimension of the revised KOF Globalisation Index consists of the two sub-dimensions: trade globalization and financial globalization. We consider this a key advantage over the 2007 version of the KOF Globalisation Index and other globalization indices. The distinction between trade and financial liberalization has already been employed in previous studies. Jaumotte et al. (2013), for example, examine how trade and financial globalization influence income distribution within a country. The results show that trade globalization was negatively associated with income inequality, and financial globalization was positively associated with income inequality. ${ }^{4}$ Kose et al. (2009) find that both trade and financial globalization influence the nexus between output volatility and growth. The effect tends to be stronger for trade globalization. Other studies, however, show that trade and financial globalization go hand in hand (see, for example, Lane and Milesi-Ferretti 2008).

\subsubsection{Measuring cultural globalization more broadly}

Another feature of the revised KOF Globalisation Index is to measure cultural globalization more broadly. We include more variables that do not rely on individual value concepts. The original selection of variables in the 2002 version of the KOF Globalisation Index was based on an understanding of cultural globalization based on Saich (2000), which defines modern cultural globalization largely as the dispersion of

\footnotetext{
${ }^{4}$ De Haan and Sturm (2017) and De Haan et al. (2018) confirm that financial development, financial liberalisation and banking crises all increase income inequality. The level of financial development and the quality of political institutions thereby condition the impact of financial liberalisation on inequality.
} 
American values. It was measured by the number of McDonald's restaurants in a country. The focus on American values was somewhat relaxed in the 2007 version of the index by including the number of IKEA stores and trade in books as additional variables. In any event, the KOF Globalisation Index has been criticized for rather measuring Westernization than cultural globalization in general. In the revised version of the KOF Globalisation Index, we include three new de facto variables measuring cultural globalization, of which none relies on an individual value concept. These variables measure trade in cultural goods, trademark applications of non-residents and trade in personal, cultural and recreational services. The variables McDonald's restaurants and IKEA stores are still included in the index.

\subsubsection{Time-varying weights for the aggregation}

The revised KOF Globalisation Index includes time-varying weighting of the individual variables in the aggregation process. As in the 2007 version of the KOF Globalisation Index, we use principal component analysis to determine the weights of the individual variables for the lowest aggregation level of the index. However, we no longer use the full sample years to determine time-invariant weights, but instead apply principal component analysis on rolling windows of 10 years to calculate time-varying weights. This procedure has the advantage of letting the weights adjust over the years to account for changes in the role of individual variables in serving as proxies for globalization.

We reassess the ability of some variables contained in the 2007 KOF Globalisation Index to measure flows of information and communication over the entire time span. Some variables in the 2007 version of the index, such as international letters, trade in newspapers and trade in books, are strongly affected by the digitalization and the internet and are gradually replaced by different information and communication channels. Ideally, we would like to include variables measuring those new channels alongside with the variables measuring the traditional channels to capture some of the substitution between the two variables over time. However, when no measures for those new means of communication are readily available for many countries, we exclude some of the previous variables. Still including these variables would indicate that social globalization is decreasing, while in fact only the means of communication are changing.

\subsection{Dimensions of the index and variable selection ${ }^{5}$}

\subsubsection{De facto economic globalization}

De facto trade globalization The sub-dimension de facto trade globalization refers to the exchange of goods and services over long distances. This is measured using the variables exports and imports of goods and exports and imports of services, both measured as a share of GDP. To account for the geographical distribution of trade

\footnotetext{
5 The full definition and source of all variables used in the KOF Globalisation Index can be found on www. kof.ethz.ch/globalisation or in Table A.1 of the appendix that is made available at the website of the Review of International Organizations.
} 
linkages, we include a variable that measures trade partner diversity. It is computed as the inverse of the average over the Herfindahl-Hirschmann trade partner concentration index for exports and imports of goods. That is, indexing countries by $i$ and their trade partners by $j$, the Herfindahl-Hirschmann index is equal to $H H I_{i}=\sum_{j=1}^{n}\left(a_{j}^{i}\right)^{2}$, where $a_{j}^{i}$ is the share of trade partner $j$ in country $i$ 's exports or imports. The more dispersed exports and imports of a country over different trade partners are, the lower $H H I_{i}$ and the higher the value of our variable. The variable trade partner diversity favors countries whose export and import structure is globally oriented as compared to countries that primarily trade regionally. Due to data limitations, we compute trade partner diversity only for trade in goods.

De facto financial globalization De facto financial globalization is measured by capital flows and stocks of foreign assets and liabilities. We thus use a quantity-based measure as opposed to a price-based or news-based measure of financial globalization (Baele et al. 2004). Kose et al. (2009) propose to focus on the sum of stocks of foreign assets and liabilities instead of flows to mitigate the problem of volatility and measurement errors in the flow variables. Following Lane and Milesi-Ferretti (2007, 2018), we include variables on foreign direct investments, portfolio investments, international debt and international reserves (excluding gold). All variables are calculated as the sum of stocks of assets and liabilities and normalized by GDP. We also include the sum of primary income payments and receipts as a share of GDP. It comprises earnings and payments arising mainly from the cross-border provision of labor and capital. For historical values of all stock variables, we rely on the updated and extended dataset External Wealth of Nations by Lane and Milesi-Ferretti (2018), which comprises information about the composition of the international financial position of a large sample of countries.

\subsubsection{De facto social globalization}

De facto interpersonal globalization This sub-dimension captures direct interactions among citizens living in different countries. The interaction can occur by the means of personal calls across borders. Personal calls are measured as international voice traffic in minutes per capita using fixed or mobile telephones. Personal contact with foreign citizens is the most likely form of direct interactions, which we measure using three variables. Migration, measured as the stock of foreign-born persons in a country, is the most persistent form, while tourism and foreign students (both counted as inbound and outbound) can be regarded as some form of temporary migration. Finally, international transfers paid and received always include some sort of personal interactions. All variables are normalized by domestic population. ${ }^{6}$

\footnotetext{
${ }^{6}$ In contrast to the 2007 version of the KOF Globalisation Index, we also normalise international transfers by population instead of GDP. By following this approach, we still account for differences in the country size as in Dreher et al. (2008), but do not carry over movements in GDP that are not directly relevant for personal contacts. Doing so is likely to emphasize the role of actors when creating personal networks.
} 
De facto informational globalization While interpersonal globalization is intended to capture personal interactions, informational globalization is meant to measure the actual flow of ideas, knowledge and images. De facto informational globalization is measured using three variables. Internet bandwidth measures the used capacity of international internet bandwidth and serves as a proxy for international digital information in- and outflows. International patents, measured as the stock of patent applications made by non-residents, describe international flows of technology, scientific knowledge and related information (OECD 2010). High technology exports describe flows of technological and scientific information. While international patents mainly describe an inflow of information, high technology exports mainly represent the outflow of information. All variables are normalized by domestic population.

De facto cultural globalization Cultural globalization is the most difficult dimension to measure. Following Saich (2000) and Dreher et al. (2008), it refers to some extent to the domination of U.S. cultural products, measured using the number of McDonald's restaurants. The definition has been expanded to western countries being trendsetters in much of the cultural realm, represented by the introduction of the number of IKEA stores to the index. In the revised version of the index, the definition is extended and new variables that do not follow an individual value concept are introduced. The stock of trademark applications by non-residents, representing the exchange of foreign trademarks, are introduced. The variable is conceptually very close to McDonald's restaurants or IKEA stores. However, it does not focus on American or any other individual culture. We also include two variables that describe the transmission of cultural values by the means of sharing cultural goods and services. Following Disdier et al. (2010), we include trade in cultural goods based on the definition by UNESCO (2009). Following Hellmanzik and Schmitz (2015), we introduce trade in personal, cultural and recreational services, a subcomponent in the Balance of Payments. It includes, for example, services related to provision of cultural goods such as production of motion pictures or musical records, organization of sport events or operation of museums. Both variables are measured as the sum of exports and imports and normalized by domestic population.

\subsubsection{De facto political globalization}

De facto political globalization captures the diffusion of government policies. It is measured using the variables participation in UN Peacekeeping missions, the number of embassies and international NGOs in a country. The presence of embassies implies foreigners acting in their home countries' interest. Hence, it is an indication of how much a government accepts foreign sovereign governmental influence and resources. International NGOs are counted as the number of internationally oriented NGOs active in a country. Similar to an embassy, the presence of international NGOs involves the influence of foreigners with political or social motives in one's own territory, which is interpreted as political influence from abroad. 


\subsubsection{De jure economic globalization}

De jure trade globalization The sub-dimension de jure trade globalization relates closely to the sub-dimension economic restriction in the 2007 version of the KOF Globalisation Index (Dreher et al. 2008). It refers to policies that facilitate and promote trade flows between countries. It is measured using variables on trade regulation, trade taxes, tariff rates and free trade agreements. Trade regulation includes the average of two subcomponents: prevalence of non-tariff trade barriers ${ }^{7}$ and compliance costs of exporting. The variable trade taxes measures the income of taxes on international trade as a share of total income in a country. The variable tariff rates refers to the unweighted mean of tariff rates. The variables trade regulation, trade taxes and tariff rates are calculated as the inverse of the normalized values such that higher values relate to a higher level of de jure trade globalization. Free trade agreements refer to the stock of multilateral and bilateral free trade agreements.

De jure financial globalization The sub-dimension de jure financial globalization measures the openness of a country to international financial flows and investments. The IMF's Annual Report on Exchange Arrangements and Exchange Restrictions (AREAER) is the primary source for most measures of de jure financial globalization (see, for example, Quinn et al. 2011). It measures the openness of the capital account of a country. We include the most widely used index based on the AREAER reports: the Chinn-Ito index (Chinn and Ito 2006, 2008). ${ }^{8}$ The second variable measures investment restrictions based on the WEF Global Competitiveness Report. To account for policies that are potentially favorable to capital flows, we include the number of international investment agreements, which covers bilateral investment agreements and treaties with investment provisions.

\subsubsection{De jure social globalization}

De jure interpersonal globalization De jure interpersonal globalization refers to policies and resources that enables direct interactions among people living in different countries. The variables we have chosen are conceptually close to the ones we use for de facto interpersonal globalization. We use the number of mobile phone and telephone subscriptions per capita. Movement of people across borders, such as migrants, tourists or students, count for a substantial amount of de facto personal contact. The variable freedom to visit represents restrictions on international travel. It measures the percentage of countries for which a country requires a visa from foreign visitors. Travel visas, alongside passports, are key control instruments of population movements by modern states (Czaika et al. 2018). The number of airports hosting international flights, normalized by population, is a measure for international connectivity.

\footnotetext{
${ }_{7}^{7}$ It is based on the WEF Global Competitiveness Reports survey question: in your country, do tariff and nontariff barriers significantly reduce the ability of imported goods to compete in the domestic market?

${ }^{8}$ The Chinn-Ito index is the first principal component of four variables: the foreign exchange regime, export proceeds, capital account and current account. A drawback of the Chinn-Ito index is that it is calculated as a five-year rolling average, which tends to introduce delays in the measurement of liberalisation policies (Karcher and Steinberg 2013).
} 
De jure informational globalization De jure informational globalization refers to the ability to share information across countries. It is measured by the number of television sets per capita. It is also measured by the number of people having access to the internet. Additionally, the press freedom index captures the availability of news related information. ${ }^{9}$ The index aims at portraying media independence and assessing the degree of print, broadcast, and digital media freedom. ${ }^{10}$

De jure cultural globalization The sub-index de jure cultural globalization refers to openness towards and the ability to understand and adopt foreign cultural influences. It is inspired by the GlobalIndex (Raab et al. 2008). The authors justify their choice of variables by highlighting their key role in quantifying the spread of common values of rationalism and hence cultural assimilation across the world. Three factors are important to measure the ability of understanding and accepting foreign cultural values. A great part of today's international culture is influenced by an egalitarian view on the role of woman in society. Consequently, we assume that having an equally egalitarian view intensifies cultural assimilation. As an approximation of such views, we include the gender parity index on gross primary school enrolment. It is an indication of parity of boys and girls and as such a strong indicator of the equality of men and women. Secondly, as a measure of education that is assumed to foster the spread of common values, we use the human capital index calculated in the Penn World Tables. Third, we include the civil freedom index, an assessment of civil liberties published in the freedom of the world report. It quantifies aspects of civil freedom such as expression and belief, associational and organizational rights, rule of law and personal autonomy and individual rights. We assume these are important elements supporting cultural globalization.

\subsubsection{De jure political globalization}

De jure political globalization refers to the ability to engage in international political cooperation. It is measured using the number of multilateral treaties signed since 1945 , the number of memberships in international organizations and a measure for the treaty partner diversity. The number of treaties and memberships in international organizations describe the communication and meetings of negotiators, with the intention to influence future relationships. They therefore rather characterize the willingness of creating networks than actual manifestation of flows. Partner constellations are informative when examining how a country influences global politics. Having the same number of treaties with a smaller number of partners rather reveals strong individual relationships than willingness to create global political networks. The variable treaty diversity measures the concentration of partners in international treaties. We use

\footnotetext{
${ }^{9}$ In the 2007 KOF Globalisation Index, the variable trade in newspapers was used to proxy information flows. With the advent of the internet, trade of newspapers are continuously replaced by the exchange of digital media. Although we no longer directly include this variable, we use press freedom to proxy the potential availability of news related information in the de jure part on informational globalisation.

${ }^{10}$ This index does not distinguish between national and international press. Hence, the validity of including the indicator rests on the assumption that national and international media is not treated differently when it comes to censoring.
} 
bilateral and not international treaties because we believe that negotiating a bilateral treaty indicates that each party was actively involved, which is not necessarily the case for international treaties. Because there is no encompassing database on bilateral treaties, we use bilateral investment treaties.

\subsection{Method of calculation}

The $2018 \mathrm{KOF}$ Globalisation Index is based on 43 individual variables, which are aggregated to a de facto and a de jure index of five sub-dimensions (trade, financial, interpersonal, informational and cultural globalization), three dimensions (economic, social and political globalization) and one total index. We distinguish between 18 different indices if we maintain the distinction between de facto and de jure. We also report the overall index for the total, for each of the three dimensions, and each of the five sub-dimensions. The overall index is calculated as the average of the de facto and the de jure index. This increases the total number of indices to 27 . This broad variety allows researchers to finetune towards those dimensions that they consider relevant for the individual research question they would like to examine.

\subsubsection{Imputation of missing data}

The KOF Globalisation Index is calculated on a yearly basis from 1970 to 2016 and for 203 countries and territories. The selection of countries and territories relies on the definitions by the World Bank. However, not all variables are available for all countries and years. Missing observations within a series are imputed using linear interpolation. Missing observations at the beginning or the end of a series are substituted by the closest observation available. Specifically, this implies that we carry the last nonmissing observation backwards in case of missing observations at the beginning of a series and forward in case of missing observations at the end of a series. Data coverage increases for most variables over time, which means that imputation of missing data is more prevalent in earlier years of our sample. ${ }^{11}$

\subsubsection{Normalizing the data}

Normalizing the data implies that each variable is transformed to an index with a scale from one to one hundred, where one hundred is assigned to the observation with the highest value across the whole sample of countries and years. The remaining observations are ranked according to the percentiles of the distribution. This panel normalization is different to annual normalization, where observations are normalized within a given year only. Panel normalization is not sensitive to outliers, which is a clear advantage over the original series. The disadvantage is that changes in the data in any year possibly affect the index value of countries in all years.

\footnotetext{
${ }^{11}$ Table A.2 in the appendix made available at the website of the Review of International Organizations shows the data coverage for all variables and selected years before imputation by displaying the share of non-missing observations. Data coverage increases from an average of $40.4 \%$ in 1975 to $81.5 \%$ in 2015 .
} 


\subsubsection{Determining the weights}

We employ principal components analysis on a 10-year rolling window to determine time-varying weights for the individual variables. We use observations for t-10 until t-1 to compute the weights for time t. The weights for the years 1970 to 1979 are set equal to the weights of the year 1980 , given the shorter time window. ${ }^{12}$ Principal components analysis partitions the variance of the variables in each sub-group and the weights are determined in a way that maximizes the variation of the resulting principal component. We calculate the weights using the entire sample of countries. By applying timevarying weights as opposed to fixed weights determined over the observations of all years, we account for structural changes in the relevance of individual variables to capture globalization over time. While the weights of individual variables vary over years, the weights of the sub-indices are determined by giving equal weights to each component and are held fixed over the sample period. Economic globalization includes trade and financial globalization, both of which receive a weight of $50 \%$ within the economic dimension. Social globalization consists of interpersonal, informational and cultural globalization, each of them contributing a third to the social globalization index. Economic, social and political globalization are aggregated to the Globalisation Index using again equal weights. The overall globalization indices are calculated as the average of the de facto and the de jure indices. Table 1 shows the weights of the different levels of the indices.

\subsubsection{Aggregation to indices}

Once the weights are determined, the aggregation consists of adding up individual weighted variables to the desired level of aggregation. Each aggregation level is calculated from the individual variables instead of using the aggregated lower-level indices. Doing so has the advantage that variables can be used in higher aggregation levels of the index, even if the value of a sub-index is not reported because of missing data. A disadvantage is that the higher ordered dimensions can only be replicated using lower ordered dimensions for countries for which all variables are available. Observations of indices are reported missing if more than $40 \%$ of the underlying variables are missing or at least two out of three sub-indices cannot be calculated.

\section{Some first comparisons and robustness checks}

\subsection{Comparing the 2018 and 2007 versions}

To compare the 2018 version with the 2007 version of the KOF Globalisation Index, we recalculate the 2007 version with the most recent data. ${ }^{13}$ Clearly, our perception of globalization did not change and despite the limitations of the earlier version of the index, the outcome of the two indices should be comparable. We calculate overall

\footnotetext{
12 Table A.3 in the appendix shows the time-varying weights of the individual variables at the lowest aggregation level for selected years.

${ }^{13}$ The 2018 vintage of the 2007 version is available on the website: http://www.kof.ethz.ch/globalisation/
} 
globalization and its dimensions as the unweighted average over all countries. The upper left panel in Fig. 1 shows the overall KOF Globalisation Index computed using the methodologies underlying the 2018 and 2007 versions. While the 2018 version shows a somewhat higher level of globalization than the 2007 version, the two series exhibit very similar patterns over time. Both measures suggest that globalization has increased most strongly between 1990 and 2007.

The increase in economic globalization between 1990 until the onset of the financial crisis 2007 is somewhat less pronounced in the 2018 version than in the 2007 version. The reason being that economic globalization in the 2018 version contains more variables reflecting de jure economic globalization than in the previous version. In particular, de jure financial globalization did not keep up with progresses in de facto financial globalization. The 2018 version exhibits higher levels of social globalization. While in the 2007 version, social globalization did not increase after 2000 , the 2018 version record continuing increases because many variables from the previous version are excluded or replaced to account for new channels of international communication. Political globalization shows the smallest differences between the 2007 and the 2018 version.

To compare individual years of the 2007 and 2018 index, we examine overlap statistics of the rankings of countries in our index. We restrict ourselves to countries that are present in both rankings. These overlap statistics are an indication of similarity. They specify the share of identical countries within the same range in both rankings. The overlap statistics of the comparison of the country rankings of the 2007 and the 2018 version of the KOF Globalisation Index are shown in Fig. 2. For each index, we show the similarity of country composition in the different quintiles of the ranking for five selected years. The first panel displays the overlap statistics of the two different versions of the overall KOF Globalisation Index. Overlap in the first quintile is equal or greater than $80 \%$ in all years but 1975 , which means that $80 \%$ of countries in the top
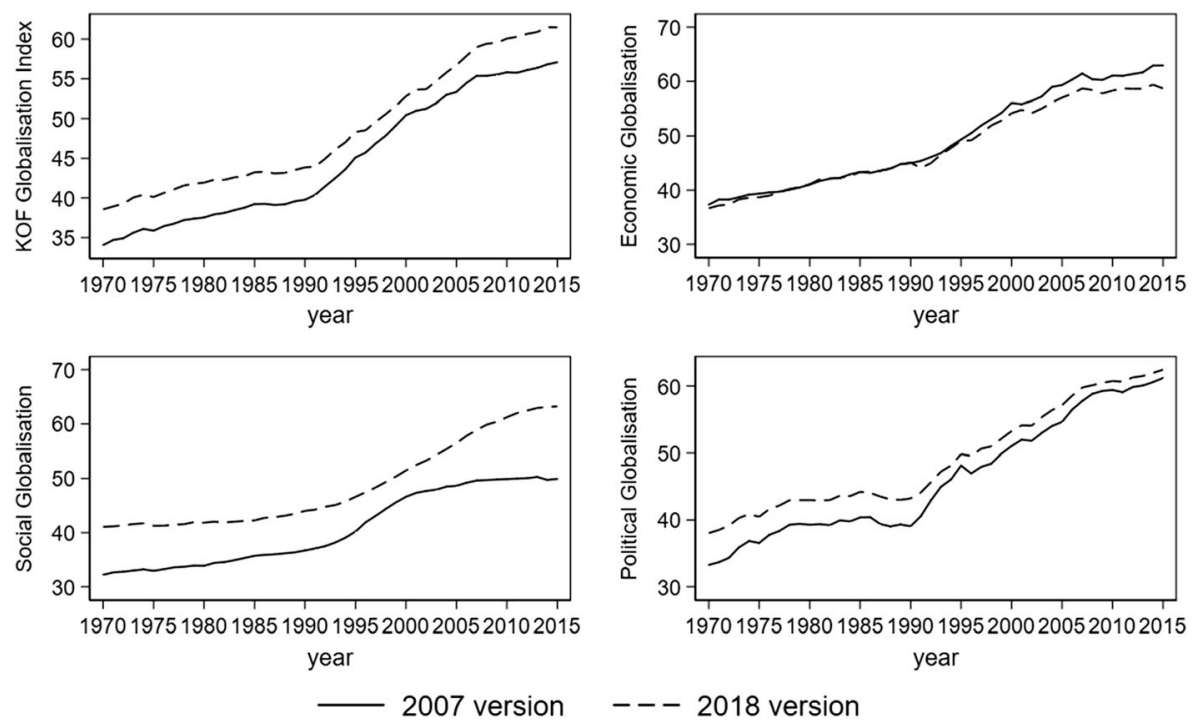

Fig. 1 KOF Globalisation Index - 2007 Version vs. 2018 Version 

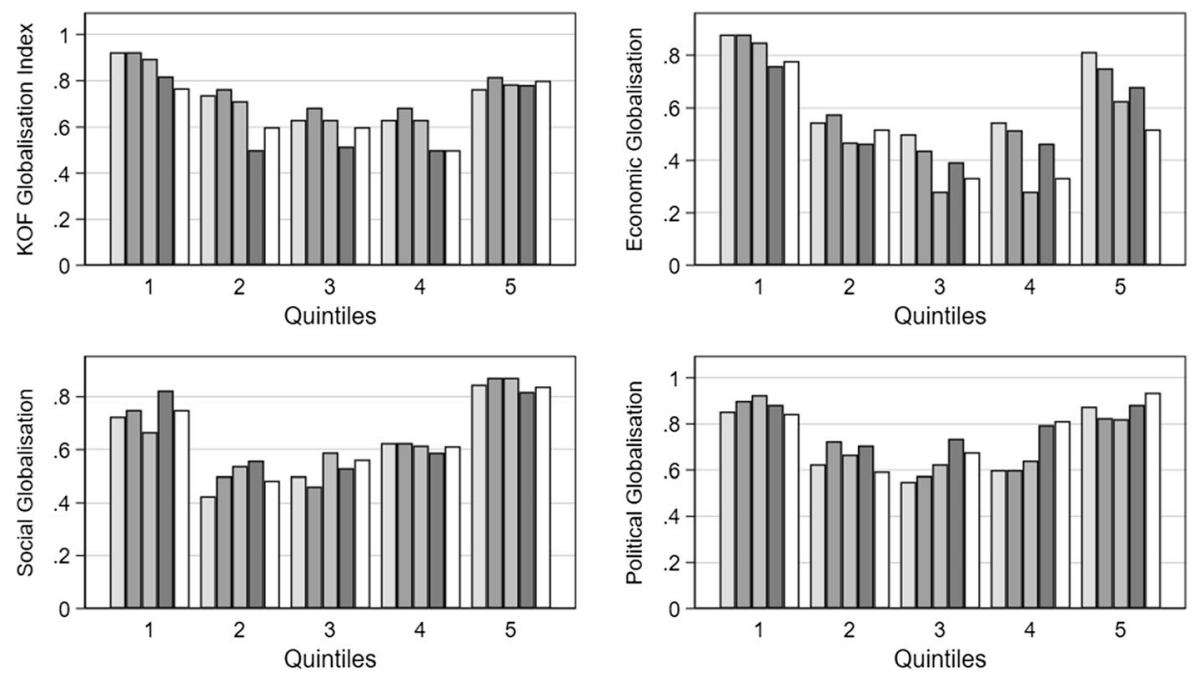

2015

2005

1995

1985

1975

Fig. 2 Overlap statistics of the 2007 and 2018 versions of the KOF Globalisation Index and its dimensions

quintiles of the index are the same in both versions. The overlap is also high in the bottom quintile with values close to $80 \%$. In the quintiles $2-4$, overlap is lower because countries in the middle of the rankings have index values that lie much closer together. Consequently, any changes from the 2007 to the 2018 version are likely to have the greatest impact on the position of countries that are in the middle part of the ranking.

\subsection{Comparing the de facto and de jure dimensions}

Developments of de facto and de jure globalization are somewhat different over time (Fig. 3). Until 1995, the world averages of de facto and de jure globalization evolve fairly similar. They start to diverge afterwards, when de jure globalization grows considerable faster than de facto globalization.

For economic globalization, both indices measure a steeper increase in de facto than in de jure globalization. While in the sub-dimension trade globalization both de facto and de jure indices increase hand-in-hand over time, de facto financial globalization increased strongly, whereas de jure financial globalization hardly increased (not shown). For social and political globalization, de jure globalization increases much more compared to de facto globalization, especially after 1990 and 1995.

The overlap statistics between the de jure and de facto indices confirm that both differ somewhat and give rise to distinct country rankings (Fig. 4). The highest overlap is achieved in the top quintiles: countries that are most globalized in the de facto indices also tend to be most globalized in the de jure indices. On the contrary, overlap in the middle quintiles is low. With a value below $50 \%$, overlap tends to be lowest for social and economic globalization. Overall, the low overlap statistics do confirm that de facto and de jure globalization describe different characteristics of globalization resulting in distinct country rankings. 

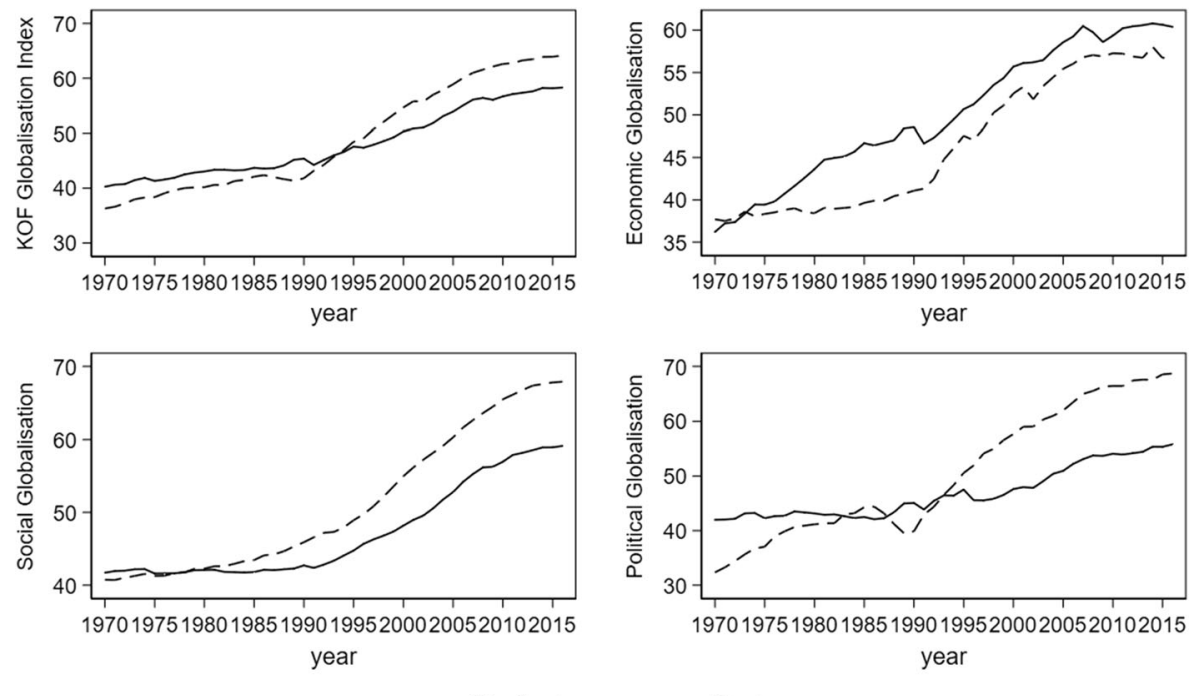

De facto

- - De jure

Fig. 3 KOF Globalisation Index - de facto versus de jure globalization

\subsection{Comparing time-varying and constant weights}

To assess the robustness of the new feature of time-varying weights, we compute the index using constant weights and compare it with the index value using time-varying weights. Overall, the index is robust to the use of constant versus time-varying weights. The two indices are strongly correlated. Time-varying weights compared to constant
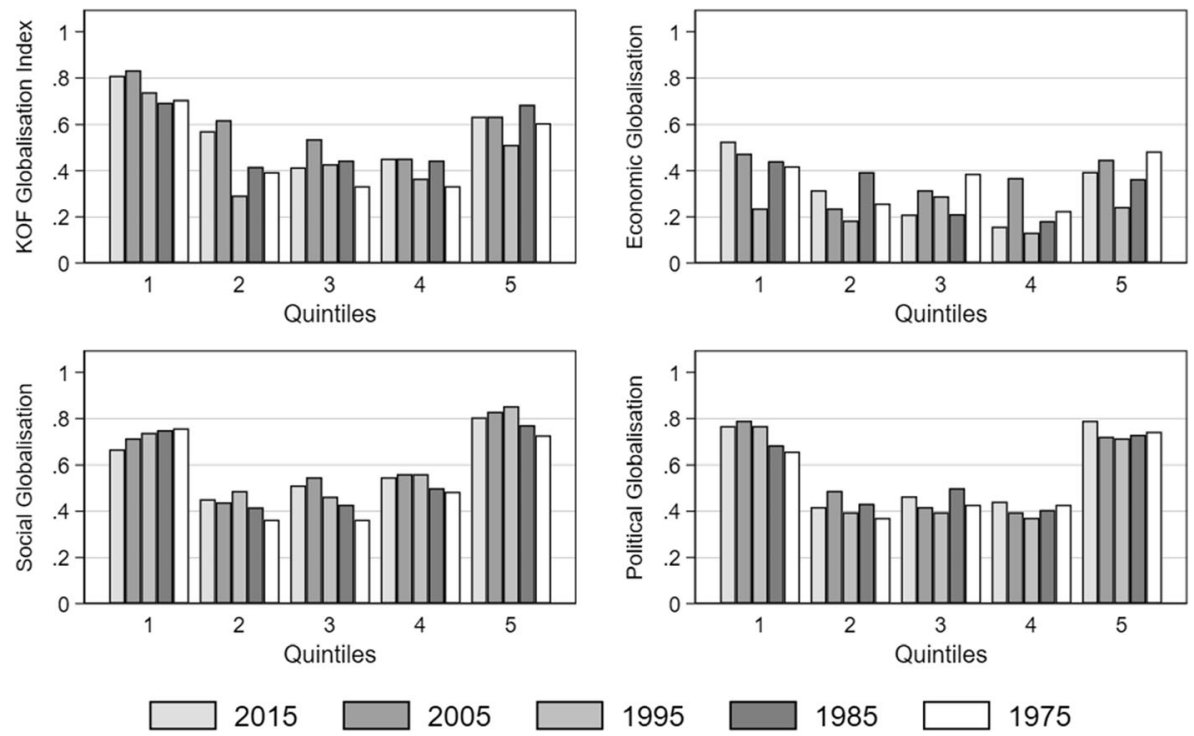

1995

1985

1975

Fig. 4 Overlap statistics of de facto and de jure measures of the KOF Globalisation Index and its dimensions 
weights raise the extent of globalization in earlier years. ${ }^{14}$ The overlap statistics show that the difference between the two indices are greatest in the economic dimension of globalization. $^{15}$

\subsection{Including/excluding cultural globalization}

Cultural globalization is arguably the most contested sub-dimension of the index. We assess the robustness of the index to the exclusion of cultural globalization. To do so, we recalculate the index without the cultural globalization sub-dimension. In this alternative index, the social dimension of globalization only contains interpersonal and informational globalization, each receiving equal weights. Figure A.3 of the online appendix shows that de facto globalization is somewhat lower with the cultural globalization dimension than without. Moreover, the comparison between de jure globalization with and without cultural globalization shows that cultural globalization developed more slowly than other dimensions of the index. The overlap statistics show that differences between the two indices are greater in the de facto part than in the de jure part. ${ }^{16}$ Overall, the index is robust to the exclusion of cultural globalization. The correlation coefficient between the two versions for the whole panel amounts to 0.99 for the overall index and 0.98 for the social globalization index.

\section{Globalization and economic growth}

As Dreher (2006), we use the new KOF Globalisation Index to examine the relationship between globalization and economic growth. We thereby show how the two new features of the revised KOF Globalisation Index - allowing disentangling de facto and de jure globalization and trade and financial globalization - are useful to arrive at new insights.

Globalization is expected to promote economic growth for manifold reasons (e.g. Grossman and Helpman 2015). First, international knowledge spillovers will certainly help to increase economic growth. They occur when knowledge acquired in one country may also be used in another country. Citizens exchange knowledge across borders. Knowledge exchange and information flows are facilitated by better infrastructure to do so: in previous decades, fax and telephones were prime examples of such infrastructure; internet access is arguably most important in this regard today. Clearly, the actual (de facto) exchange of knowledge and information flows promote economic growth rather than institutions that facilitate information flows (de jure). Second, entrepreneurs have access to larger potential markets in open than closed economies. An entrepreneur, who used to serve the domestic market of its home country, enjoys much more opportunities to attract customers in foreign countries when governments abolish tariffs and capital account restrictions and international trade and investments in foreign countries become more attractive. Economic globalization also

\footnotetext{
${ }^{14}$ See Figure A.1 in the online appendix.

${ }^{15}$ See Figure A.2 in the online appendix.

${ }^{16}$ See Figure A.4 in the online appendix.
} 
increases competition because foreign investors enjoy the very same benefits than domestic entrepreneurs and enter domestic markets. Third, entrepreneurs may well exploit comparative advantages and receive gains from specialization during globalization. Production will become more efficient and increase a country's economic growth.

Theoretical predictions about whether de facto globalization influences economic growth to a larger extent than de jure globalization (or vice versa) are difficult to arrive at. De jure globalization is often a prerequisite for de facto globalization. For example, tariffs need to be reduced or abolished to promote international trade. Infrastructure such as internet access needs to be available to exchange information and ideas. International agreements need to be signed and embassies built to enable political collaboration. When de jure globalization has occurred, de facto globalization proceeds. Goods and services need to be traded, information exchanged, and policies in line with international agreements implemented. It remains an empirical question how de facto and de jure globalization influence economic growth. Future theoretical research may help making more fine-grained predictions that are tested empirically.

Empirical studies suggest that globalization promote economic growth. The first study using the 2002 version of the KOF Globalisation Index to measure globalization was Dreher (2006). His sample includes 123 countries over the period 1970-2000. The results suggest that overall globalization was quite strongly and positively correlated with economic growth. Disentangling the aspects of globalization suggests that especially actual economic flows, restrictions in developing countries and information flows increase growth. Other previous studies suggest that rather developing instead of industrialized countries enjoy economic growth during globalization. In countries of the Organization of Islamic Cooperation (OIC), for example, economic globalization (as measured by the $2007 \mathrm{KOF}$ Globalisation Index) has been shown to promote economic growth (Samini and Jenatabadi 2014). For instance, Bergh and Karlsson (2010) present evidence for OECD countries.

We use the new KOF Globalisation Index to examine whether globalization promotes economic growth. The sample includes 137 developed and developing countries over the period 1975-2010. We follow related studies such as Dreher (2006) and estimate the model based on five-year averages. The baseline panel data model has the following form:

$$
\text { Economic Growth }_{\mathrm{it}}=\alpha_{\mathrm{j}} \text { Globalization }_{\mathrm{ijt}}+\Sigma_{\mathrm{k}} \gamma_{\mathrm{jk}} \mathrm{X}_{\mathrm{ikt}}+\eta_{\mathrm{i}}+\varepsilon_{\mathrm{t}}+\mathrm{u}_{\mathrm{ijt}} \text {, }
$$

with $i=1, \ldots, 137 ; j=1, \ldots, 27 ; k=1, \ldots, 9 ; t=1, \ldots, 9$. The dependent variable Economic Growth $_{\text {it }}$ is the average annual growth rate of GDP per capita within a fiveyear period in country $\mathrm{i}$ and period t. Globalization $\mathrm{ijt}_{\mathrm{it}}$ is the KOF Globalisation Index averaged over each five-year period. We run the regression for all 27 subindices $\mathrm{j}$ of the KOF Globalisation Index. $\Sigma_{\mathrm{k}} \mathrm{X}_{\mathrm{ikt}}$ contains nine control variables, $\eta_{\mathrm{i}}$ is a fixed country effect, $\varepsilon_{\mathrm{t}}$ is a fixed period effect and $\mathrm{u}_{\mathrm{ijt}}$ is the error term. We follow Dreher's (2006) main specification for the selection of the control variables. The initial level of GDP per capita at each of the five-year periods measures 
the conditional rate of convergence to the steady state growth rate. We employ the human capital index published by the Penn World Tables (Feenstra et al. 2015) as an indicator of human capital. ${ }^{17}$ The $\log$ of life expectancy is included for the same reason. Since higher population growth should directly give rise to lower per capita economic growth, the log of the fertility rate is also included. Higher domestic investment as a share of GDP should give rise to higher growth rates, whereas the effect of higher government consumption is not obvious a priori. On the one hand, a large government sector may induce inefficiencies and crowd out the private sector. On the other hand, the provision of an efficient infrastructure and a proper legal framework may promote growth (De Haan and Sturm 2000). To account for the quality of the legal system and the enforceability of property rights, we use the rule of law index as part of the economic freedom index constructed by Gwartney et al. (2018). Better institutions are likely to promote growth. Finally, the change in a country's terms of trade and its rate of inflation are included. Both have been shown to have a significant effect on growth in some previous studies. Table 3 shows summary statistics and the underlying sources for all the variables.

Column (1) of Table 4 reports the result of the main specification: the KOF Globalisation Index has a positive effect on medium-term growth. Although the sample using the new index includes 137 instead of 123 countries, the most important coefficient estimates remain of similar size and significance. In their robustness analysis, Sturm and De Haan (2005) report that in these growth regressions in particular initial income and the investment share are found to be robust and consistent across many specifications. This is, once again, confirmed here. We, in line with Dreher (2006), also find that the rule of law index and life expectancy plays some positive role. Most importantly, though, our key variable of interest, the point estimate of the KOF Globalisation Index, is positive and statistically significant at the $1 \%$ level.

Columns (2) to (4) report results when each of the underlying economic, social and political indices are used separately. In line with Dreher (2006), the results show that all three dimensions are relevant for growth, whereby the coefficient size of the social dimension is roughly twice that of the other two dimensions.

In contrast to the previous versions of the KOF Globalisation Index, we are now able to distinguish between de facto and de jure dimensions. The first two columns of Table 5 suggest that it is the de jure dimension that is driving the positive relationship between globalization and growth. The coefficient estimate for the de facto overall measure is positive, but of smaller size and only statistically significant at the $10 \%$ level. The coefficient estimate of the de jure part is almost double in size and statistically significant at the $1 \%$ level. A ten-point increase in the de jure measure of globalization is associated with an increase in the annualized growth rate of about 1.4 percentage points. ${ }^{18}$

\footnotetext{
${ }^{17}$ Dreher (2006) actually uses the secondary school enrolment rate. However, this measure is not available for as many countries and years. It (also) does not turn out to be statistically significant when nevertheless used. ${ }^{18}$ If both variables are included in the same specification, we find that, despite potential multicollinearity problems, the de jure coefficient remains statistically significant whereas the de facto coefficient lacks statistical significance. A simple F-test reveals that we can reject the null-hypothesis that both coefficients are equal.
} 
Table 3 Descriptive statistics and data sources. Economic growth

\begin{tabular}{|c|c|c|c|c|c|c|}
\hline & $\mathrm{N}$ & Mean & SD. & Min & Max & Source \\
\hline GDP per capita growth & 823 & 1.90 & 3.14 & -13.41 & 23.01 & Penn World Table 9.0 \\
\hline $\log ($ Initial level of GDP per capita) & 823 & 8.96 & 1.17 & 6.02 & 12.26 & Penn World Table 9.0 \\
\hline Human capital index & 823 & 2.28 & 0.69 & 1.02 & 3.70 & Penn World Table 9.0 \\
\hline $\log ($ life expectancy) & 823 & 4.19 & 0.17 & 3.38 & 4.41 & $\begin{array}{l}\text { World Bank - World } \\
\text { Development Indicators }\end{array}$ \\
\hline $\log ($ fertility rate $)$ & 823 & 1.09 & 0.55 & -0.07 & 2.07 & $\begin{array}{l}\text { World Bank - World } \\
\text { Development Indicators }\end{array}$ \\
\hline Investment ( $\%$ of GDP) & 823 & 21.52 & 9.12 & 1.65 & 60.24 & Penn World Table 9.0 \\
\hline Government consumption ( $\%$ of GDP) & 823 & 18.51 & 8.62 & 3.10 & 64.36 & Penn World Table 9.0 \\
\hline Rule-of-law index & 823 & 5.00 & 1.86 & 0.99 & 9.07 & $\begin{array}{l}\text { Economic Freedom of } \\
\text { the World }\end{array}$ \\
\hline Inflation rate & 823 & 4.29 & 6.67 & -16.26 & 29.78 & Penn World Table 9.0 \\
\hline Growth rate of terms of trade & 823 & 0.72 & 2.97 & -14.86 & 28.32 & Penn World Table 9.0 \\
\hline KOF Globalisation Index & 823 & 55.15 & 16.11 & 21.87 & 89.88 & this study \\
\hline KOF Economic Globalisation Index & 823 & 50.70 & 16.97 & 14.56 & 94.70 & this study \\
\hline KOF Social Globalisation Index & 823 & 50.51 & 21.83 & 6.54 & 91.02 & this study \\
\hline KOF Political Globalisation Index & 823 & 64.15 & 18.05 & 16.70 & 98.45 & this study \\
\hline KOF Trade Globalisation Index & 823 & 48.65 & 18.41 & 10.65 & 96.57 & this study \\
\hline KOF Financial Globalisation Index & 823 & 52.75 & 18.14 & 5.74 & 96.68 & this study \\
\hline KOF Interpersonal Globalisation Index & 823 & 48.51 & 21.40 & 5.00 & 90.85 & this study \\
\hline KOF Informational Globalisation Index & 823 & 52.56 & 22.60 & 3.04 & 94.54 & this study \\
\hline KOF Cultural Globalisation Index & 823 & 50.46 & 23.81 & 7.26 & 94.60 & this study \\
\hline KOF Globalisation Index, de facto & 823 & 53.68 & 15.73 & 19.31 & 91.62 & this study \\
\hline KOF Globalisation Index, de jure & 823 & 56.64 & 17.55 & 15.61 & 93.12 & this study \\
\hline KOF Economic Globalisation Index, de facto & 823 & 49.48 & 18.54 & 8.71 & 98.39 & this study \\
\hline KOF Economic Globalisation Index, de jure & 823 & 51.92 & 20.15 & 12.68 & 95.32 & this study \\
\hline KOF Social Globalisation Index, de facto & 823 & 48.22 & 23.72 & 3.54 & 96.67 & this study \\
\hline KOF Social Globalisation Index, de jure & 823 & 52.78 & 20.95 & 7.46 & 91.27 & this study \\
\hline KOF Political Globalisation Index, de facto & 823 & 63.10 & 20.12 & 19.16 & 97.45 & this study \\
\hline KOF Political Globalisation Index, de jure & 823 & 65.19 & 18.84 & 2.50 & 99.57 & this study \\
\hline KOF Trade Globalisation Index, de facto & 823 & 47.56 & 19.99 & 5.23 & 99.16 & this study \\
\hline KOF Trade Globalisation Index, de jure & 823 & 49.70 & 24.72 & 6.71 & 96.75 & this study \\
\hline KOF Financial Globalisation Index, de facto & 823 & 51.40 & 20.94 & 6.23 & 98.99 & this study \\
\hline KOF Financial Globalisation Index, de jure & 823 & 54.07 & 19.87 & 3.50 & 95.41 & this study \\
\hline KOF Interpersonal Globalisation Index, de facto & 823 & 47.08 & 24.31 & 2.82 & 96.56 & this study \\
\hline KOF Interpersonal Globalisation Index, de jure & 823 & 49.98 & 20.26 & 4.20 & 91.52 & this study \\
\hline KOF Informational Globalisation Index, de facto & 823 & 52.90 & 24.44 & 2.61 & 98.31 & this study \\
\hline KOF Informational Globalisation Index, de jure & 823 & 52.21 & 22.72 & 2.55 & 97.61 & this study \\
\hline KOF Cultural Globalisation Index, de facto & 823 & 44.55 & 26.39 & 2.04 & 96.85 & this study \\
\hline KOF Cultural Globalisation Index, de jure & 823 & 56.16 & 23.58 & 5.88 & 96.84 & this study \\
\hline
\end{tabular}

Columns (4) and (8) suggest that this de jure result is driven by both the economic and political dimensions - the de jure parts of these are both statistically significant at 
Table 4 Growth regressions. Baseline

\begin{tabular}{|c|c|c|c|c|}
\hline \multirow[t]{2}{*}{ Variables } & (1) & $(2)$ & (3) & (4) \\
\hline & Overall & Economic & Social & Political \\
\hline \multirow[t]{2}{*}{ KOF Globalisation Index } & $0.164 * * *$ & $0.0774 * * *$ & $0.166^{* * * *}$ & $0.0581 * *$ \\
\hline & $(0.0498)$ & $(0.0284)$ & $(0.0474)$ & $(0.0277)$ \\
\hline \multirow[t]{2}{*}{$\log$ (Initial level of GDP per capita) } & $-6.428 * * *$ & $-6.294 * * *$ & $-6.551 * * *$ & $-6.001 * * *$ \\
\hline & $(0.891)$ & $(0.896)$ & $(0.945)$ & $(0.836)$ \\
\hline \multirow[t]{2}{*}{ Human capital index } & 0.627 & 1.198 & 0.254 & 0.873 \\
\hline & $(1.594)$ & $(1.582)$ & $(1.599)$ & $(1.576)$ \\
\hline \multirow[t]{2}{*}{$\log ($ life expectancy $)$} & $5.122 * *$ & $5.491 * *$ & $3.984 *$ & $4.838^{*}$ \\
\hline & $(2.468)$ & $(2.489)$ & $(2.233)$ & $(2.639)$ \\
\hline \multirow[t]{2}{*}{$\log ($ fertility rate) } & -0.0864 & -0.835 & -0.00398 & -0.549 \\
\hline & $(1.033)$ & $(0.953)$ & $(1.016)$ & $(1.003)$ \\
\hline \multirow[t]{2}{*}{ Investment (\% of GDP) } & $0.132 * * *$ & $0.142^{* * *}$ & $0.131 * * *$ & $0.135^{* * * *}$ \\
\hline & $(0.0327)$ & $(0.0325)$ & $(0.0323)$ & $(0.0329)$ \\
\hline \multirow[t]{2}{*}{ Government consumption ( $\%$ of GDP) } & 0.0352 & 0.0339 & 0.0300 & 0.0430 \\
\hline & $(0.0363)$ & $(0.0371)$ & $(0.0363)$ & $(0.0366)$ \\
\hline \multirow[t]{2}{*}{ Rule-of-law index } & 0.222 & $0.226^{*}$ & $0.255^{*}$ & $0.266^{*}$ \\
\hline & $(0.139)$ & $(0.136)$ & $(0.145)$ & $(0.139)$ \\
\hline \multirow[t]{2}{*}{ Inflation rate } & 0.00677 & 0.0115 & 0.000767 & 0.00730 \\
\hline & $(0.0212)$ & $(0.0223)$ & $(0.0217)$ & $(0.0215)$ \\
\hline \multirow[t]{2}{*}{ Growth rate of terms of trade } & 0.0519 & 0.0500 & 0.0542 & 0.0553 \\
\hline & $(0.0408)$ & $(0.0401)$ & $(0.0409)$ & $(0.0419)$ \\
\hline Observations & 823 & 823 & 823 & 823 \\
\hline R-squared & 0.364 & 0.354 & 0.361 & 0.347 \\
\hline Number of countries & 137 & 137 & 137 & 137 \\
\hline
\end{tabular}

Standard errors are in parentheses

${ }^{*} p<0.1,{ }^{* *} p<0.05,{ }^{* * * *} p<0.01$

the $1 \%$ level. As these de jure measures most likely reflect slowly developing institutional changes and therefore can be assumed to be relatively exogenous, this hints at a causal relationship between globalization and growth. The de jure KOF Social Globalisation Index does, on the other hand, not turn out to be statistically significant. Within the social dimension, it is actually the de facto part that matters, both qualitatively and quantitatively. The coefficient estimate of de facto globalization is 0.13 and statistically significant at the $1 \%$ level. A higher degree of social de facto globalization goes hand in hand with higher growth. We believe that this result is very well in line with the international knowledge spillover theory. Citizens need to actually exchange knowledge and information across borders to promote growth. Just having institutions established to exchange knowledge and information does not yet give rise to effects on economic growth.

Digging one level deeper and looking at the sub-dimensions of economic and social globalization allows us to distinguish between, first, trade-related and financial 


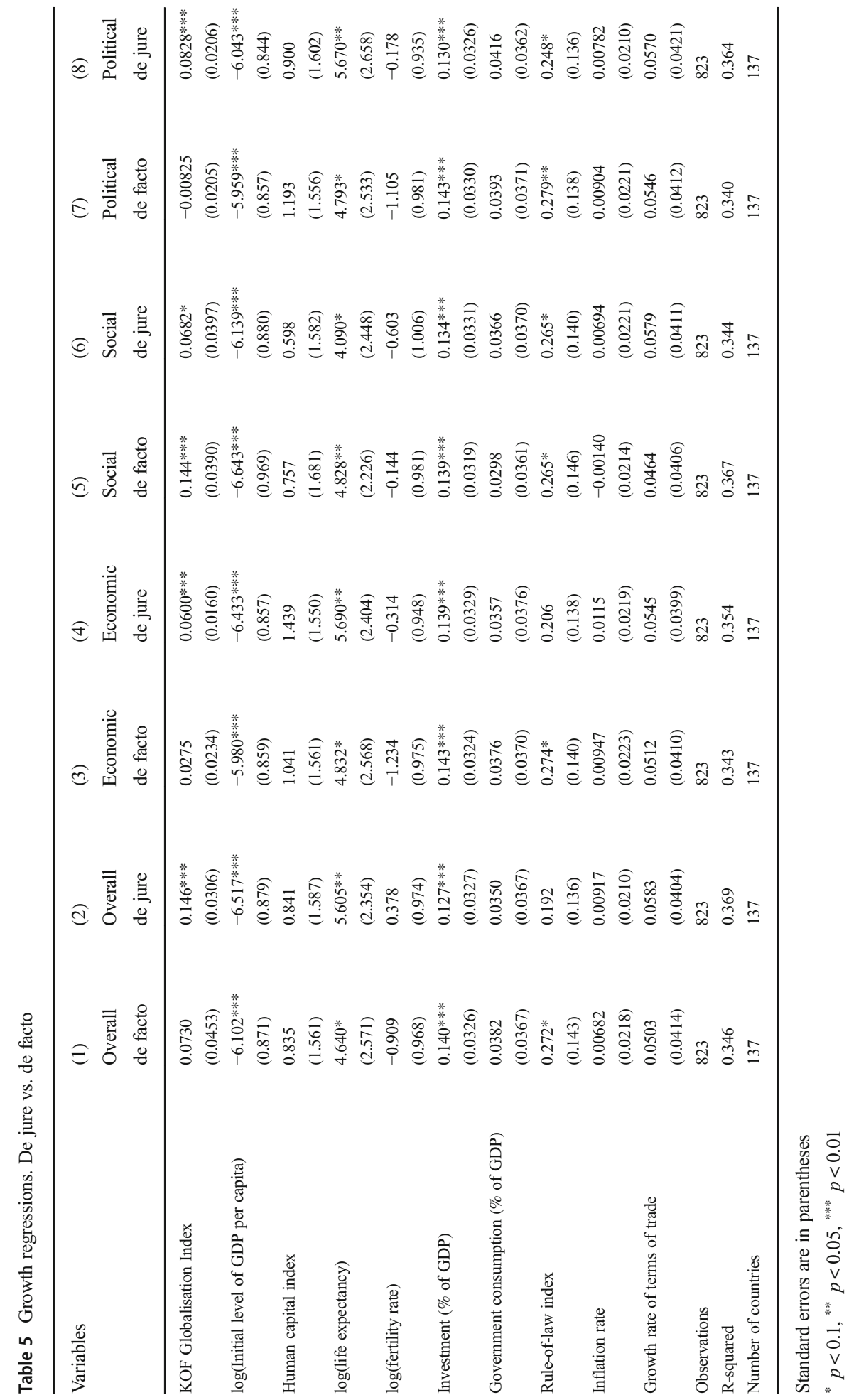


globalization and, second, interpersonal, informational and cultural globalization. Table 6 indicates that every sub-dimension is important for growth. While the coefficient has the same size for trade and financial globalization, it appears that interpersonal globalization has the biggest effect on growth within the social dimension of globalization.

Table 7 distinguishes between de facto and de jure in the sub-dimensions. The first four columns of Table 7 indicate that institutional liberalization appears to have a positive impact on growth for the trade and financial dimension of globalization. This corroborates the results from Quinn et al. (2011) for financial globalization. As to be expected given the results in Table 5 in which de facto social globalization appear more influential than its de jure part, all three de facto sub-dimensions within social globalization have a significantly positive impact on growth. In any event, the de jure interpersonal globalization measure is statistically significant at the 5\% level. De jure cultural globalization, on the other hand, has a negative impact on growth, albeit lacks

Table 6 Growth regressions. Economic and Social sub dimensions

\begin{tabular}{|c|c|c|c|c|c|}
\hline \multirow[t]{2}{*}{ VARIABLES } & (1) & (2) & (3) & (4) & $(5)$ \\
\hline & Trade & Financial & Interpersonal & Informational & Cultural \\
\hline \multirow[t]{2}{*}{ KOF Globalisation Index } & $0.0541 * *$ & $0.0438 * *$ & $0.146 * * *$ & $0.0669 * *$ & $0.0764 * *$ \\
\hline & $(0.0239)$ & $(0.0205)$ & $(0.0467)$ & $(0.0293)$ & $(0.0346)$ \\
\hline \multirow[t]{2}{*}{$\log$ (Initial level of GDP per capita) } & $-6.150 * * *$ & $-6.186^{* * *}$ & $-6.363 * * *$ & $-6.322 * * *$ & $-6.151 * * *$ \\
\hline & $(0.876)$ & $(0.884)$ & $(0.876)$ & $(0.900)$ & $(0.903)$ \\
\hline \multirow[t]{2}{*}{ Human capital index } & 1.298 & 1.086 & 0.651 & 0.976 & 0.366 \\
\hline & $(1.554)$ & $(1.590)$ & $(1.582)$ & $(1.598)$ & $(1.580)$ \\
\hline \multirow[t]{2}{*}{$\log ($ life expectancy) } & $4.420^{*}$ & $5.842 * *$ & $5.087 * *$ & $4.198^{*}$ & $4.103^{*}$ \\
\hline & $(2.467)$ & $(2.561)$ & $(2.364)$ & $(2.376)$ & $(2.370)$ \\
\hline \multirow[t]{2}{*}{$\log ($ fertility rate $)$} & -0.622 & -1.150 & -0.336 & -0.421 & -0.692 \\
\hline & $(0.956)$ & $(0.964)$ & $(1.012)$ & $(1.023)$ & $(0.909)$ \\
\hline \multirow[t]{2}{*}{ Investment (\% of GDP) } & $0.141 * * *$ & $0.142 * * *$ & $0.127 * * *$ & $0.137 * * *$ & $0.140 * * *$ \\
\hline & $(0.0330)$ & $(0.0323)$ & $(0.0327)$ & $(0.0333)$ & $(0.0321)$ \\
\hline \multirow[t]{2}{*}{ Government consumption ( $\%$ of GDP) } & 0.0379 & 0.0348 & 0.0269 & 0.0368 & 0.0368 \\
\hline & $(0.0372)$ & $(0.0371)$ & $(0.0375)$ & $(0.0373)$ & $(0.0360)$ \\
\hline \multirow[t]{2}{*}{ Rule-of-law index } & $0.271 *$ & $0.226^{*}$ & $0.265^{*}$ & $0.288^{*}$ & $0.243^{*}$ \\
\hline & $(0.140)$ & $(0.133)$ & $(0.142)$ & $(0.146)$ & $(0.139)$ \\
\hline \multirow[t]{2}{*}{ Inflation rate } & 0.0102 & 0.0107 & 0.00545 & 0.00307 & 0.00595 \\
\hline & $(0.0224)$ & $(0.0220)$ & $(0.0216)$ & $(0.0222)$ & $(0.0216)$ \\
\hline \multirow[t]{2}{*}{ Growth rate of terms of trade } & 0.0552 & 0.0488 & 0.0459 & 0.0571 & 0.0561 \\
\hline & $(0.0402)$ & $(0.0407)$ & $(0.0410)$ & $(0.0411)$ & $(0.0419)$ \\
\hline Observations & 823 & 823 & 823 & 823 & 823 \\
\hline R-squared & 0.350 & 0.347 & 0.363 & 0.347 & 0.349 \\
\hline Number of countries & 137 & 137 & 137 & 137 & 137 \\
\hline
\end{tabular}

Standard errors are in parentheses

${ }^{*} p<0.1,{ }^{* *} p<0.05,{ }^{* * *} p<0.01$ 


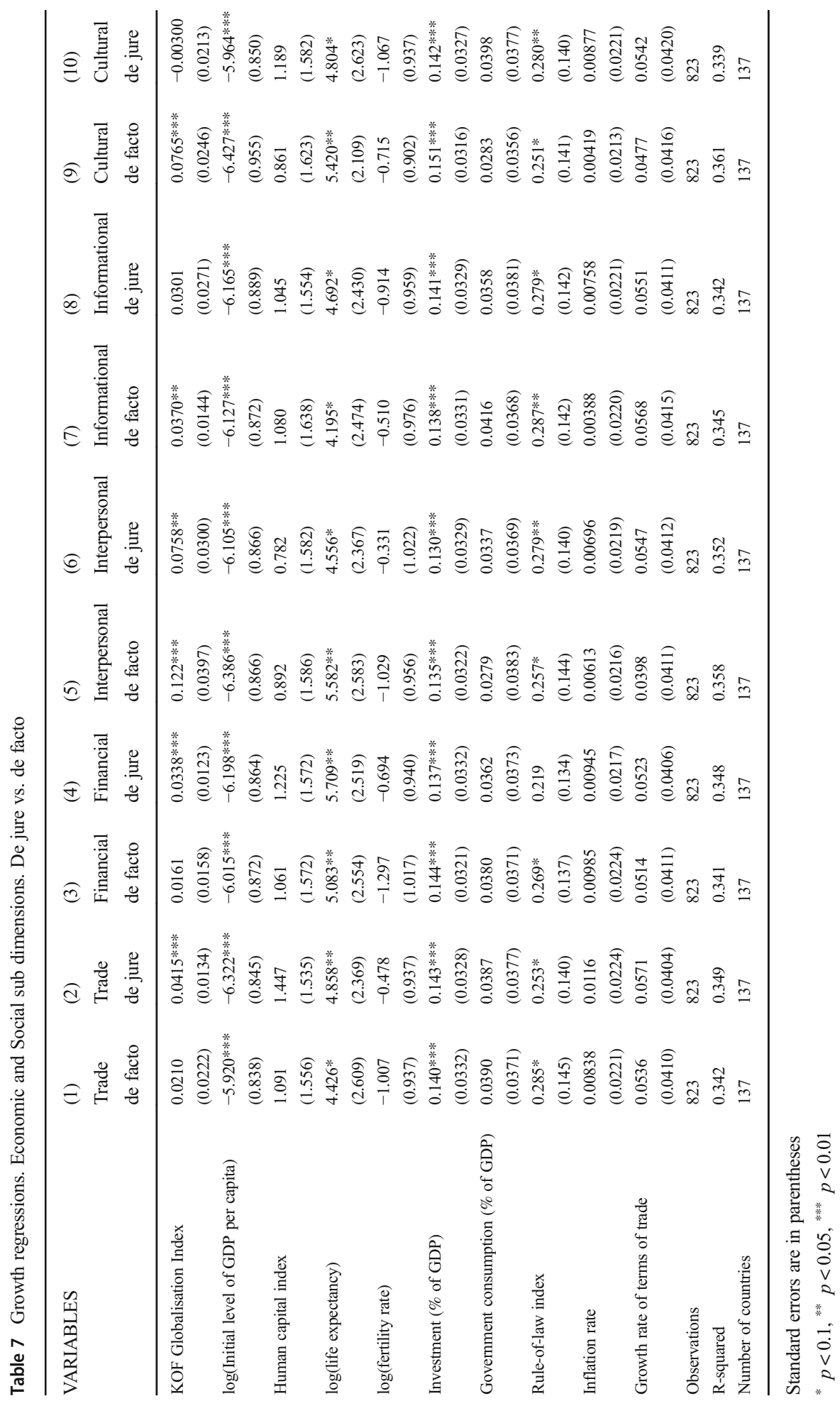


statistical significance. The relative importance of de facto over de jure measures again confirm the international knowledge spillover theory: having the infrastructure available to exchange persons, information or culture is not necessarily sufficient to foster growth. Needed are actual flows.

We have also estimated subsamples for OECD and non-OECD countries (the results are available in the appendix). The results show that overall, economic, social and political globalization promoted economic growth in non-OECD countries. The four globalization indices are statistically significant at the 5\% level. By contrast, the results do not suggest that globalization promote economic growth in OECD countries: the four globalization indices lack statistical significance. This result corroborates previous studies such as Bergh and Karlsson (2010) and Dreher (2006). For OECD and nonOECD countries, de jure economic globalization is statistically significant, while de facto economic globalization is not. In the social dimension, the results show that the positive effect of de facto social globalization is driven by non-OECD countries. De jure social and de facto political globalization lack statistical significance in both subsamples as in the full sample.

\section{Conclusions}

This paper has introduced the third version of the KOF Globalisation Index, a composite index measuring globalization for basically every country in the world since 1970. In line with its previous two versions, the third version of the KOF Globalisation Index distinguishes between economic, social and political globalization. The new KOF Globalisation Index has been improved in many ways as compared to the previous 2007 version. We have increased the number of underlying variables from 23 to 43 variables to measure the encompassing concept of globalization more precisely. The two major innovations are (a) distinguishing between de jure and de facto globalization and (b) introducing a separate index within the dimension of economic globalization measuring financial globalization. We also allow the weights of the underlying variables to slowly change over time by incorporating time-varying weights in the aggregation procedure.

We have used the new 2018 KOF Globalisation Index to look into the effects of globalization on economic growth. The results corroborate previous studies showing that countries enjoy economic growth when globalization is proceeding rapidly. Economic, social and political globalization are positively associated with economic growth, especially in developing countries. In contrast to previous research, we are able to distinguish between de facto and de jure globalization and find that these have different effects: economic growth increases when de jure economic and political globalization and de facto social globalization are more pronounced. Countries that reduce institutional restrictions to trade in goods and services and financial flows and that are politically integrated enjoy on average higher economic growth. The effect of de facto social globalization corroborates that the informational knowledge spill-over theory: citizens need to really exchange knowledge and information to promote economic growth; institutions and infrastructure that may potentially be used for exchanging knowledge, but in fact is not, do not help to increase economic growth. 
De jure globalization is often a prerequisite for de facto globalization. There is a good case to make why both de jure and de facto globalization are likely to influence outcomes such as economic growth. Future research should develop theories describing under which conditions de jure and/or de facto globalization is expected to influence outcomes such as economic growth.

Including manifold variables in an encompassing index always gives rise to discussions about whether individual variables are suitable. We believe that distinguishing between de facto and de jure globalization is useful for all three aspects of economic, social, and political globalization. Because we use principal component analysis, we need at least three individual variables to measure de facto and de jure globalization in every dimension. By providing in total 27 different measures of globalization, we, however, do allow researchers to pick those that appear most relevant for their particular research question. Hence, when scholars disagree about the suitability of some individual subcomponents included, they may well concentrate on other parts of the revised KOF Globalisation Index.

On the other hand, some might argue that we should have included even more variables. However, as this globalization indicator will be updated on a yearly basis, it is important that only variables are included that are regularly updated as well. Next to our aim to cover as many countries and years as possible, this limits the number of potential variables that we can use considerably.

We hope that by providing this new version of the KOF Globalisation Index, the research community will be in a better position to examine the consequences and the underlying drivers of globalization. Especially distinguishing between de facto and de jure measures and allowing for a clear separation between trade and financial globalization are in our view important and new assets that hopefully allow us to dig even deeper than before.

Acknowledgements We thank Dennis Quinn and Stefan Sperlich for valuable discussions and Axel Dreher and three anonymous reviewers for comments. This paper was written while Savina Gygli was working at KOF. The views expressed are those of the authors and do not necessarily reflect those of the SNB. The usual disclaimer applies.

Open Access This article is distributed under the terms of the Creative Commons Attribution 4.0 International License (http://creativecommons.org/licenses/by/4.0/), which permits unrestricted use, distribution, and reproduction in any medium, provided you give appropriate credit to the original author(s) and the source, provide a link to the Creative Commons license, and indicate if changes were made.

Publisher's Note Springer Nature remains neutral with regard to jurisdictional claims in published maps and institutional affiliations.

\section{References}

A.T. Kearney. (2018). 2018 Global Cities Report. Chicago.

A.T. Kearney/Foreign Policy. (2001). Measuring globalization. Foreign Policy, (122), 56-65.

Babones, S. J., \& Farabee-Siers, R. M. (2008). Indices of trade partner concentration for 183 countries, 19802008. Journal of World-Systems Research, 18(2), 266-277.

Baele, L., Ferrando, A., Hördahl, P., Kyrlova, E., \& Monnet, C. (2004). Measuring European financial integration. Oxford Review of Economic Policy, 20(4), 509-530. 
Bergh, A., \& Karlsson, M. (2010). Government size and growth: Accounting for economic freedom and globalization. Public Choice, 142(1-2), 195-213.

Caselli, M. (2012). Trying to measure globalization, experiences, Critical Issues and Perspectives. Springer Briefs in Political Science.

Caselli, M. (2013). Nation states, cities, and people. SAGE Open, 3(4), 215824401350841.

Chinn, M., \& Ito, H. (2006). What matters for financial development? Capital controls, institutions, and interactions. Journal of Development Economics, 81(1), 163-192.

Chinn, M., \& Ito, H. (2008). A new measure of financial openness. Journal of Comparative Policy Analysis, 10(3).

Clark, W. C. (2000). Governance in a Globalizing World, Environmental globalization, p. 86-108. Brookings Institution Press.

Czaika, M., de Haas, H., \& Villares-Varela, M. (2018). The global evolution of travel visa regimes. Population and Development Review, 44(3), 589-622.

De Haan, J., \& Sturm, J.-E. (2000). On the relationship between economic freedom and economic growth. European Journal of Political Economy, 16(2), 215-241.

De Haan, J., \& Sturm, J.-E. (2017). Finance and income inequality: A review and new evidence. European Journal of Political Economy, 50, 171-195.

De Haan, J., Pleninger, R., \& Sturm, J.-E. (2018). Does the impact of financial liberalization on income inequality depend on financial development? Applied Economics Letters, 25(5), 313-316.

De Lombaerde, P.D. \& Iapadre, L.P. (2008). Chapter 21 International Integration and Societal Progress: A Critical Review of Globalisation Indicators. Statistics, Knowledge and Policy 2007: Measuring and Fostering the Progress of Societies.

Disdier, A.-C., Tai, S., Fontagné, L., Mayer, T. (2010). Bilateral trade of cultural goods. Review of World Economics, 145(4), 575-595.

Dreher, A. (2006). Does globalization affect growth? Evidence from a new index of globalization. Applied Economics, 38(10), 1091-1110.

Dreher, A., Gaston, N., \& Martens, P. (2008). Measuring globalisation - gauging its consequences. New York: Springer.

Dreher, A., Gaston, N., Martens, P., \& Van Boxem, L. (2010). Measuring globalization - Opening the black box. A critical analysis of globalization indices. Journal of Globalization Studies, 1(1), 166-185.

Feenstra, R. C., Inklaar, R., \& Timmer, M. P. (2015). The next generation of the Penn world table. American Economic Review, 105(10), 3150-3182.

Feld, L.-P., \& Voigt, S. (2003). Economic growth and judicial Independence: Cross-country evidence using a new set of indicators. European Journal of Political Economy, 19(3), 497-527.

Figge, L., \& Martens, P. (2014). Globalisation continues: The Maastricht globalisation index revisited and updated. Globalizations, 7731(April), 1-19.

Ghemawat, P. \& Altman, S. A. (2016). DHL global connectedness index 2016 - The State of Globalization in an Age of Ambiguity.

Grossman, G., \& Helpman, E. (2015). Globalization and growth. American Economic Review, 105(5), 100104.

Gwartney, J., Lawson, R., \& Hall, J. (2018). Economic freedom of the world.

Hellmanzik, C., \& Schmitz, M. (2015). Virtual proximity and audiovisual services trade. European Economic Review, 77, 82-101.

Jaumotte, F., Lall, S., \& Papageorgiou, C. (2013). Rising income inequality: Technology, or trade and financial globalization? IMF Economic Review, 61(2), 271-309.

Karcher, S., \& Steinberg, D. A. (2013). Assessing the causes of capital account liberalization: How measurement matters. International Studies Quarterly, 57(1), 128-137.

Kluver, R., \& Fu, W. (2004). The cultural globalization index. Foreign Policy.

Kose, M. A., Prasad, E., Rogoff, K., \& Wei, S.-J. (2009). Financial Globalization: A Reappraisal. IMF Staff Papers, 56(1), 8-62.

Lane, P. R., \& Milesi-Ferretti, G. M. (2007). The external wealth of nations mark ii: Revised and extended estimates of foreign assets and liabilities, 1970-2004. Journal of International Economics, 73(2), 223250 .

Lane, P. R., \& Milesi-Ferretti, G. M. (2008). The drivers of financial globalization. American Economic Review, 98(2), 223-250.

Lane, P. R., \& Milesi-Ferretti, G. M. (2018). The external wealth of nations revisited; international financial integration in the aftermath of the global financial crisis. IMF Economic Review, 66(1), 189-222.

Lockwood, B. (2004). How robust is the Kearney/foreign policy globalisation index? The World Economy, 27(4), 507-524. 
Lockwood, B. \& Redoano, M. (2005). The CSGR globalisation index: An introductory guide. Technical report 155 (04), CSGR working paper.

Martens, P., Caselli, M., De Lombaerde, P., Figge, L., \& Scholte, J. A. (2015). New directions in globalization indices. Globalizations, (August): 1-12.

Norris, P. (2000). Governance in a Globalizing World, global governance and cosmopolitan citizens, p. 155177. Brookings Institution Press.

Nye, J. S. \& Keohane, R. O. (2000). Governance in a Globalizing World, Introduction, p.144. Brookings Institution Press.

OECD (2010). Measuring globalisation, OECD Economic Globalisation Indicators.

Potrafke, N. (2015). The evidence on globalisation. The World Economy, 38(3), 509-552.

Quinn, D. P., Schindler, M., \& Toyoda, M. A. (2011). Assessing measures of financial openness and integration. IMF Economic Review, 59(3), 488-522.

Raab, M., Ruland, M., Schonberger, B., Blossfeld, H.-P., Hofacker, D., Buchholz, S., \& Schmelzer, P. (2008). GlobalIndex: A sociological approach to globalization measurement. International Sociology, 23, 596631.

Rosendorf, N. M. (2000). Governance in a Globalizing World, Social and Cultural Globalization: Concepts, History, and Americas Role, page 109-134. Brookings Institution Press.

Saich, T. (2000). Globalization, governance, and the authoritarian Westphalian state: The case of China. Globalization and Governance, pages 208-228.

Samini, P., \& Jenatabadi, H. S. (2014). Globalization and economic growth: Empirical evidence on the role of complementarities. PLoS One, 9(4), 1-7.

Scholte, J. A. (2008). Defining globalisation. The World Economy, 13(11), 1471-1502.

Sturm, J.-E., \& De Haan, J. (2005). Determinants of long-term growth: New results applying robust estimation and extreme bounds analysis. Empirical Economics, 30(3), 597-617.

UNESCO (2009). The 2009 UNESCO framework for cultural statistics (FCS). UNESCO.

Voigt, S., Gutmann, J., \& Feld, L.-P. (2015). Economic growth and judicial Independence, a dozen years on: Evidence using an updated set of indicators. European Journal of Political Economy, 38, 197-2011.

Vujakovic, P. (2010). How to measure globalisation? A new globalisation index (NGI). Atlantic Economic Journal, 38(2), 237-237.

World Bank. (2018). World development indicators (WDI). Washington DC. 